\title{
Accounting
}

\section{Macroeconomic effect on stock price: Evidence from Indonesia}

\section{Andung Luwihono ${ }^{a}$, Benny Suhermana, Darmawanta Sembiringa, Syahrir Rasyid ${ }^{a}$, Nawang Kalbuana $^{b^{*}}$, Riyanto Saputro ${ }^{b}$, Budi Prasetyo ${ }^{b}$, Taryana ${ }^{b}$, Yayuk Suprihartini ${ }^{b}$, Pribadi Asih ${ }^{b}$, Zainal Mahfud ${ }^{\mathrm{c}}$ and Rusdiyanto ${ }^{\mathrm{d}}$}

\author{
${ }^{a}$ Jayapura Aviation Polytechnic, Kayubatu St. No. 6, Tanjung Ria, Jayapura, Papua 99117, Indonesia \\ ${ }^{b}$ Politeknik Penerbangan Indonesia Curug, Jl. Raya PLP Curug, Serdang Wetan, Kec. Legok, Tangerang, Banten 15820 Indonesia \\ ${ }^{c}$ Faculty of Economics, Universitas Madura, Jl Raya Panglegur Km 3.5 Pamekasan, East Java, Indonesia \\ ${ }^{d}$ Faculty of Economics and Business, Universitas Airlangga Indonesia, Jl. Airlangga No.4, Airlangga, Gubeng, Surabaya, East Java 60286 Indonesia
}

\section{H R O N I C L E}

Article history:

Received: January 1, 2021

Received in revised format:

January 232021

Accepted: February 10, 2021

Available online:

February 10, 2021

Keywords:

Engineering Managers

Budget Plan (RAB)

Macroeconomics

Stock prices

\section{A B S T R A C T}

Investment decision making by Engineering Managers needs to take into account microeconomic and macroeconomic factors in a country. The role of Engineering Managers in making decisions is crucial and very important. Technical Managers need to consider macro-economic effects such as the US dollar exchange rate against the rupiah, the interest rate set by Bank Indonesia, inflation, especially during the preparation of the Budget Plan (RAB). This research is to analyze the macroeconomic effect on stock prices, to prove the hypothesis, a quantitative approach is used. Macroeconomics are assessed through the US dollar exchange rate, and financial statements data of banking companies.

\section{Introduction}

(C) 2021 by the authors; licensee Growing Science, Canada

Technical Managers need to consider macro-economic effects such as the US dollar exchange rate against the rupiah, the interest rate set by Bank Indonesia, inflation, especially during the preparation of the Budget Plan (RAB). Banks are intermediaries who truly need community involvement in their function, banking products and services are used, similarly, the bank demands that the public raise money for banking purposes. Since the bank's business activity involves fundraising and channeling, the financial institution must maintain public trust, in order to deposit its resources with the bank, and therefore it needs to maintain its health condition by applying the Principle of Caution. Regulatory capital models consider the effect of liquidity risk on stock price (Alfonsi et al., 2020; Asmah et al., 2020; Cai et al., 2020; Gajek \& Rudź, 2020; Kupiec, 2020; Rehfeldt et al., 2020; Tran et al., 2020), The higher the capital ratio (P. Li et al., 2020; Luque, 2020; Murthy \& Ketenci, 2020; Rabbani, 2020; Ueda \& Sharma, 2020), the less liquidity risk there is (Chakravarty \& Ray, 2020; Navas et al., 2020; Shanaev et al., 2020; Smaoui et al., 2020; Z. J. Wang et al., 2020), so it will impact the stock Price (Chitradevi, 2019; Flores-Muñoz et al., 2019; X. Wang et al., 2019). The second thought argues that higher capital ratios reduce financial fragility so that it increases financial resilience (Bezemer et al., 2020; Escobar et al., 2020; Humpe \& McMillan, 2020; Kind et al., 2020; Kuhl et al., 2020; Pennerstorfer et al., 2020; Pollard et al., 2020).

* Corresponding author.

E-mail address: nawang.kalbuana@ppicurug.ac.id (N. Kalbuana) 


\section{Literature review}

Budget Plan (RAB) is the calculation of the amount of costs required for materials, tools and wages, as well as other costs related to the implementation of the work or project. Each engineering manager must be able to create, analyze every RAB he will make. Technical Managers need to consider macro-economic effects such as the US dollar exchange rate against the rupiah, the interest rate set by Bank Indonesia, inflation, especially during the preparation of the Budget Plan (RAB). Unemployment is when production factors are not actively involved in the production that is willing and capable of producing goods and services (Anglada, 2016; Aulin-Ahmavaara, 1989; Dernbach, 2004; Mahboob et al., 2012). Unemployment does not mean that the economy has the macroeconomic goals of absorbing all employees. Unemployment is a real problem because production is lower; thus, in the economy, scarcity occurs because the unemployed earn less income that gradually lowers their living standards (Bański \& Wesołowska, 2020; Malanima, 2018; Mehmood et al., 2018; Millar, 2009; Minot et al., 2006; Shen et al., 2012). Generally, if the economy grows from time to time, it is observed. GDP growth rates and unemployment rates, generally low, are indicative of economic growth (Azolibe et al., 2020; Gelfer, 2020; Jumpah et al., 2020; Karlsson \& Österholm, 2020; Martín Álvarez et al., 2020; P. H. Nguyen et al., 2020). This is because GDP is rising, the output is increasing, and the number of employees required to balance output levels increases. A good economic situation is usually going to have lower unemployment and vice versa (Barbosa-Filho, 2020; Carvalho et al., 2020; Glawe \& Wagner, 2020; Samy-Kamal, 2020; Turner \& Giordano, 2020; Zhang et al., 2020).

Inflation will arise if prices rise consistently and continuously (Cagliarini et al., 2011; Fooladi et al., 2020; Hubmann et al., 2020; Škare, 2012; Vaona, 2013; Yücel, 2018). In Inflation, the price of goods and services is indicated by the general increase occasionally. In these cases, prices usually rise year after year or month to month. The economy is not achieving its stability objectives with this burden (Bordo \& Jeanne, 2004; Jonáš, 2001; Leith \& Wren-Lewis, 2009; "Prices: No Inflation Fear," 2000; "The Budget and Economic Outlook: Fiscal Years 2010 to 2020," 2011; Silver, 2000; Sims, 1999). The average price of goods and services increases with inflation. Some prices are higher than average in terms of inflation, some below average and even falling commodity prices. The real problem is inflation because of the reduction in money buying power because the prices of products and services are increasing. This will, in turn, decrease financial wealth and livelihoods and increase long-term planning uncertainty. Wealth and revenue are generally spread carelessly across different industries and between resources (Ahmed \& Kar, 2019; Aslanbeigui \& Oakes, 2015; Blanchett, 2014; Bulut \& Collins, 2014; Bykanova et al., 2017; Drometer et al., 2018; Fahy Bryceson \& Bosse Jønsson, 2013).

Inflation and unemployment are likely to occur, at various stages in the business cycle (Brown et al., 1976; Ploch, 2011; Tyler, 1982). There will be a different chance of this problem. Sometimes the problem of unemployment falls, and inflation is something that should be taken into account. In other cases, more than inflation, unemployment needs to be considered. We will now see how these two issues relate to the two main business phases. During the recession, in general economic activity will decrease. Total aggregate demand is lowered, resulting in less production and less utilization of resources during the manufacturing process. This is the main problem of unemployment. At the same time, however, as markets tend to exceed shortages, Inflation in this phase is usually not a problem (Bersch et al., 2019; Farjadi et al., 2018; Gamble, 2018; Hindess, 2017). Economic activity increases during the expansion stage. The overall rise in demand for aggregates leads to higher production levels and higher resources. Thus, the major problem at this stage tends to be inflation. However, many people are required to meet work request with strong production and therefore unemployment is not a problem (Iqbal Anjum, 1996; T. Nguyen, 2011; Robinson \& Wade, 1985; Welfens \& Kauffmann, 2005).

Tariffs of interest are charges charged by banks for lending. Companies sometimes borrow the money and thus increased interest rates will directly impact the company (Aleem, 1990; Do et al., 2020; Sandberg, 2015; Sapienza, 2004; Sherer Jr. et al., 2004; Stenning \& Shearing, 1984). With the rise in interest rates, interest expenses will increase. The company must raise the cost in order to pay the loan in these cases. Customers also suffer from change in interest rates. This also affects the enterprise. In such cases, To borrow money, people have to pay a greater amount, which causes large products to decrease. Stagnant growth occurs if the supply of products doesn't increase or fall too below the benchmark (Krishnan et al., 2020; Lynn et al., 2020; Sauzède et al., 2020; Usman \& Nichol, 2020; J. Yang et al., 2019; Yusnaini \& Nur, 2020). Economic growth generally requires increased total production of goods and services (Andari et al., 2019; Bahadori \& Kashiwao, 2019; Deng et al., 2018; Ren et al., 2019; Schlüter et al., 2019; Sutherland \& Ralph, 2019). This is necessary to offset the population increase and expectations of better living standards. If total output does not meet those expectations, growth is stagnant. Consequently, economic growth's macroeconomic objectives are not met. This makes it possible to combine stagnant growth with production resource quantity and quality. Detailed cause of stagnant growth. Production growth can be reduced by the number of four factors in production (Cole \& Rosengaus, 2019; Huang et al., 2020; Kim et al., 2018; Mousavian \& Eskandari, 2018). These factors include capital, land, labor, and business (Delgado et al., 2008; Martin et al., 2015). 
Banks are all banks, including companies, institutions, and business processes (Bataev et al., 2018; Castillo-Carmelino et al., 2020; Helbekkmo et al., 2019; Shorter \& Seitzinger, 2012; Wilson et al., 2014; Zveryakov et al., 2019), to be as follows defined: 1. Banks are companies that raise funds and redistribute them to the community through loans or other forms so that people's lives improve, 2. Conventional bank is a bank whose business activities are carried out conventionally and on the basis of its kind classified as commercial and rural lending banks. 3. Sharia banks, banks whose business activities are carried out using Sharia Principles consisting of Sharia Rural Financing and Sharia Commercial Banks (Darwanto \& Chariri, 2019; Fidiastutik \& Roziq, 2019; Kartika et al., 2019; Mukhibad \& Setiawan, 2020; Ramli et al., 2020; Zulfikar \& Sri, 2019). Malkiel and Fama, (1970) says an efficient market is a prerequisite in which bond prices fully reflect the information available. Market prices also react fast to new data that reflect stock price changes. In order to measure data effectively, the link between stock prices but also accounting information is examined. But what data is used to conduct effective market evaluations? (S. Brown et al., 1999), cites three major types of market efficiency: weaknesses, weak markets, semi-powerful forms and strong efficiency on the market. Valuable relevance research is interpreted as a study to establish if the value of financial statements is related to the capital market's stock price. Relevant and reliable financial reports must be created. Financial reports are considered to be important when they can be useful in predicting and confirm a business decision. Financial statements are considered important when their numbers relate strongly to the value of a company (Čabinová et al., 2020a, 2020b; Cancela et al., 2020; "Erratum Regarding Missing Declaration of Competing Interest Statements in Previously Published Articles (Journal of Accounting Education (2020) 51, (S0748575120300245), (10.1016/j.Jaccedu.2020.100670))," 2020; Ertimur et al., 2020; Tharp, 2020), in the financial statement (Craja et al., 2020; Eberhartinger et al., 2020; Hasan et al., 2020; Lien et al., 2020; Martens et al., 2020; Yilmaz et al., 2020). Research on value relevance is split into 3, namely: a, in 'The relevance of literature pertaining to financial standard situations (W. Cai \& Ye, 2020; Derevyankina \& Yankovskaya, 2020; Hu \& Song, 2020; Ozdemir et al., 2020; Yu et al., 2020; Zakharchenko et al., 2020).' Relative association (Comparison of land market value and alternative size, for example, the relationship between income and inventory prices), b. Studies of increased association (research whether certain financial report figures are useful for stock market explanation and return), c. Marginal studies of contents of information (This study examines whether certain accounts add information available to investors to the collection. The model (Ohlson, 1995) is the most well-known value model for the connection between business value and accounting. Ohlson's model is also an accounting model itself that includes a model that covers key values of financial intelligence. The model of Ohlson is a strong theoretical market evaluation framework that is based on basic accounting and other information related to corporate value prediction. The model is simple, in the Model investors are assuming that they are neutral, accounts are non-biased, there is no clear surplus, the role in accounting is not detailed, there is no asymmetry of information, inconsistency of tax rates, explicitly calculated actual choices and an abnormal profit and "v" self-records. In the (Ohlson, 1995) model the company's value as indicated in the stock price can be seen in (Juanamasta et al., 2019; Prabowo et al., 2020; Rusdiyanto, Agustia, et al., 2020; Rusdiyanto, Hidayat, et al., 2020; Syafii et al., 2020).

$N P_{t}=N B_{t}+\alpha_{1} L A_{1}+V L_{t}$

The above equation shows that the company's value (NPt) in time $t$ depends on the rupiah exchange rates against the USD, Inflation SBI, and other data (VLt) which is constantly multiplied ( $\alpha 1$ and $\alpha 2)$, respectively. Thus, it can be determined that the function of company value is:

$N P_{t}=f\left(U S D, S B I, I N F, V L_{t}\right)$

Feltham and Ohlson (1995) were surprising, since it was simple to derive, however, the need for predictive dividends was eliminated, with an equal value to the current value of all expectations of dividends, when calculating the value of the company. The value is a result of the position of an investor in an enterprise reflected in the enterprise's market price. The stock price of the company reacts to the company's overall status describing the shareholder/company asset wealth investment decisions, financing, and asset management under inventory prices of companies (Cardi \& Mazzoli, 2019; Schuenemann et al., 2020; Shishany et al., 2020; Vukovic et al., 2020; Zhan et al., 2020). One factor in the performance of companies in the country is the macroeconomic condition of a country (Additya, Singa, and Maulana, 2018), which can influence the movements in stock price. Investors will be greatly helped in making profitability decisions on investment by understanding and predicting macroeconomic conditions in the future so that investors can predict macroeconomic conditions in the future, and investors should also pay attention to many macroeconomic indices that are able to help them in understanding and predicting the condition of the macroeconomic. (Additya et al., 2018). Macroeconomic indicators frequently related to capital markets include fluctuation in unemployment, IDR exchange rates, inflation, interest rate, and staggered growth. The IDR exchange rate is the currency determined by the Indonesian banks based on their decision. It was valid until 1997, under the established exchange policy. Following 1997, demand and supply or market mechanisms released the IDR exchange rate versus the Dollar. The global economy entered the era of globalization, influencing movement in emerging financial markets of foreign capital. Sensitivity of the capital market is obvious in domestic fluctuations in currencies ( $\mathrm{Li}$ et al., 2017; Manzoor \& Haqiqi, 2012) in Indonesia that adheres to a fluctuating exchange rate and Rupiah appreciation may have an international impact on local competitiveness. This can reduce the output of the company to lower stock prices. If the Rupiah value decreases, the investment portfolio in which US 
dollar holding investors May the Indonesian capital market check in potential domestic industries tend to increase the US dollar value by foreign investors that hold shares in the Indonesian stock exchange. The hypothesis of the research can be formulated, based on the description above:

$\mathrm{H}_{1}$ : The IDR dollar exchange rate have a positive impact on stock prices.

Banks directly controls the interest rate via the BI rate. The response rate of bank to achieve its intended goal (Adamović et al., 2020; Barasa et al., 2018; Mallett et al., 2012; Yalcin et al., 2014) is a BI rate that will continue to increase. The Bank of rate reflects the position on monetary policy or position set and announced by the BI to the public. Policy of low interest promotes investments rather than savings, and vice versa. The hypothesis of the research can be formulated, based on the description above:

\section{$\mathrm{H}_{2}$ : The interest rate of BI has a positive impact on stock prices.}

Inflation generally leads to a deterioration in the purchasing power of the public, because income levels are actually also declining (Gut et al., 2015). Development and economic dynamics affect Increased goods and services demand, one of the reasons behind inflation). The hypothesis of the research can be formulated, based on the description above:

\section{$\mathrm{H}_{3}$ : The inflation has a positive impact on the stock price.}

\section{Methodology}

In this study using quantitative Explanatory research. "Explanatory research is a research method which aims at explaining the position of the studied variables and the effects on one variable for another," said (Juanamasta et al., 2019; Prabowo et al., 2020; Rusdiyanto, Agustia, et al., 2020; Rusdiyanto, Hidayat, et al., 2020; Syafii et al., 2020). The quantitative methods are research which aims to understand as well as solve problems refers to positive or empirical considerations. The study focuses on testing theory, in particular. A sample comprises the number and features of the population. This study uses a purposeful sampling method. The intended sample is a method for determining samples for certain reasons. Sample data are inventory prices, IDR dollar currency data, interest rates for BI and inflation. There were 1,280 of a four Persero bank listed companies on the Indonesian Stock Exchange from 2010 to 2017 in this study. The library method in this research is used to obtain valid data in the form of figures taken from several literature such as the Internet, newspapers, books, and other related topics. Additionally, the publications of IDR Exchange Rate for US dollar, The Indonesian Bank's rate, inflation 2010-2017 are using the documentation techniques used in this research in the context of data searches Price reports in stock form. The data collection methodology is provided online by using www.idx.co.id, www.yahoofinancing.com, www.bi.go.id. In this study, ten dependent variables are used to create a regression model to measure the importance of corporate reporting. In this study, the variables included:

\subsection{Variable}

\subsubsection{Dependent Variable}

The dependent variable in this study is the company's value at the end of the month, which is supported by the bond market price. Price or value of stocks that are held at a specified point of time on the market, based on market situation, on the share capital market (Bouteska \& Regaieg, 2020; Chiang, 2020; T. K. Nguyen \& Razali, 2020; Osazevbaru \& Tarurhor, 2020; Ricci et al., 2020).

\subsubsection{Independent Variable}

1. The IDR's exchange rate are the exchange rate established on the basis of the Indonesian banks' decision. It was only until 1997 that the exchange rate policy was in force. After 1997, demand and supply and market mechanisms released the US dollar IDR exchange rate. Banks Indonesia not only monitors and control market mechanisms Policy for intervention in the market by releasing dollars from the Indonesian (Anggitawati \& Ekaputra, 2020; Darman \& Hutomo, 2020; Rahim et al., 2020; Saenong et al., 2020; Saidi et al., 2020).

2. Stated that interest could be understood as remuneration for customers who purchase and sell their products by banks that follow conventional principles. The interest rate shall be money amount paid in a percentage by the borrower to the debtor. This study's interest rate is the interest rate of a Bank deposit for the one-year period of monitoring. The interest rate and for a quarter shall be adjusted to an SBI interest rate (BC \& Esfahani, 2020; Fullerton \& Muñiz, 2020; J. Nguyen \& Valadkhani, 2020; P. R. Yang, 2020; Zhenyu \& Taltavull, 2020). 
3. The inflation described as an event describing a position in which goods prices increase and currency value weakens. According to the consumer price index must be first calculated before the annual inflation calculation is made or may be referred to as the Price index of customers (Walossek et al., 1996). The inflation calculation formula is:

Inflation $=\frac{I H K_{s}-I H K_{k}}{I H K_{k}} \times 100 \%$

where $I H K_{s}$ and $I H K_{k}$ are current and previous price index, respectively.

\section{Discussion}

In this study the analysis model used tests the impact of the independent variables also on depending variable that use multiple regression analysis to show the correlation structure between two or more independent variables. The empirical research model is as follows:

$$
N P_{t}=\alpha+\beta_{1} U S D+\beta_{2} S B I+\beta_{3} I N F+\varepsilon
$$

Table 1 introduces the information on Eq. (1).

Table 1

Description of the parameters

\begin{tabular}{cl}
\hline Information & \multicolumn{1}{c}{ Description } \\
\hline$N P_{t}$ & $=$ Stock price \\
$\alpha$ & $=$ Constants \\
$\beta 1, \beta 2, \beta 3$ & $=$ Variable regression coefficient $N B_{t}, U S D, S B I, I N F$, \\
$U S D$ & $=$ IDR Exchange Rate Against USD \\
$S B I$ & $=$ BI Interest Rate \\
$I N F$ & $=$ Inflation \\
$\epsilon$ & $=$ Standard Error \\
\hline
\end{tabular}

\subsection{Research Results Description}

Descriptive analysis is necessary to provide an overview of the fluctuating variables used in this study to describe the research data's properties. The normality of the data is also tested for the distribution of the research information used. Results of the sample selection resulted in 1.280 data from four publicly owned companies in the Indonesian stock exchange listed in Indonesia which fulfilled the pre-determined criteria. The statistical data in this sample are descriptive.

\section{Table 2}

Descriptive Statistics

\begin{tabular}{|c|c|c|c|c|c|}
\hline Variable & $\mathrm{N}$ & $\min$ & $\max$ & mean & Std. Dev. \\
\hline Stock price & 128 & 470.00 & 1327.00 & 5721.1484 & 3395.3951 \\
\hline Exchange Rate IDR/USD & 128 & 9097.00 & 14657.00 & 11520.0312 & 1761.46531 \\
\hline BI Interest Rate & 128 & 121.00 & 7363.00 & 4005.3438 & 26.41 .41861 \\
\hline Inflation & 128 & 3.07 & 8.40 & 5.2172 & 1.48160 \\
\hline Valid N & 128 & & & & \\
\hline
\end{tabular}

The IDR-US dollar and BI exchange rate is high in relation with inflation from the above table. Inflation is below the IDR dollar exchange rate, and the BI exchange rate is well below the rupiah exchange rate of the dollar. Fair value components of BI rate are higher than financial asset and liability inflation. Successive IDR exchange rate increases in US dollars and BI rate indicate that the company includes information about its relevance to its financial assets regarding the fair value of the company. In other phrases, the exchange rate size for IDR is greater than the US dollar, and BI is higher than Inflation. When the RBI rate is set to increase, the dollar IDR exchange rate varies and stabilizes against the banks' stock prices.

\subsection{Regression Analysis}

All variables in the study are stable at degree 0 and can be used in a regression model directly. Results of the research variables regression will be shown below: 
Table 3

Regression Analysis

\begin{tabular}{lccc}
\hline Variable & Coefficient & $\mathrm{t}$ & Sig. t \\
\hline Constant & 7077.986 & 1.147 & 0.254 \\
Exchange Rate of IDR/USD & 0.185 & 3.477 & 0.001 \\
BI interest rate & 0.109 & 1.496 & 0.137 \\
Inflation & 193.490 & -1.150 & 0.253 \\
$\mathrm{R}=0.743$ R-Square $=0.552 \mathrm{~F}=16.167(0.000)$ & & & \\
\hline
\end{tabular}

The IDR currency has positive and influence on the dollar at 5 percent of a stock price. The result of the study means the value for stock prices of the US dollar exchange rate for IDR. The coefficient reveals a positive relation to equity prices in the IDR exchange rate to the US dollar. Investors can evaluate the stock price of a bank by using the IDR exchange rate to US dollar. IDR currency is a general anticipation for investors. From test results, investors will be keener on inventories that have a high IDR dollar-to-US exchange rate than stocks with a low IDR-to-US dollar exchange rate. Due to many investor requests for a high rate of rupiah share exchange the company's stock market price rises. In contrast to the US dollar, the IDR's low exchange rate tends to bring down stock prices. The study results conform to the findings of its study (Malau, 2018), while the variable adverse IDR exchange rate has a substantial impact on stock prices (R. Sari, 2018). The results of the VAR analysis show this, The t-statistic values are greater than the t-table value when the VAR estimate results show table values with a confidential 95 percent level of confidence. BI interest rates do not influence stock prices positively and significantly. BI interest rates do not apply with respect to stock prices, the study's results indicate. The correlation shows that the BI rate is not positive in relation to bank sector companies' share price. Investors can use the information on interest rates to assess the share prices of banking companies. For investors, the BI interest rate is indeed a general forecast. It can be said from the findings of this test that investors have a higher BI rate than stocks with lower BI interest rates. Firm's stock prices rise with a large number of requests made by investors for high BI interest rates. In contrast, a low rate of BI tends to affect the stock price. This study is not consistent with its results (Sari, 2018). Inflation doesn't influence stock prices positively and substantially. The findings of this study show that inflation is irrelevant to stock prices. These results show the inflation rate is not positively related to the bank sector's stock prices. Investors can use inflation rate information to assess the bank sector's share price. The inflation rate for investors is generally expected. The results of this test suggest that investors are more interested in high inflation stocks than in low inflation stocks. The amount of investor demands for high inflation stocks increases the company's inventory price. On the contrary, a low rate of inflation tends to influence the stock price to decrease. The results of the research differ from his findings.

\section{Conclusion}

Results of the test show a positive and significant statistical effect of rrupiah's exchange rate against the US dollar at a 5 percent share price, while the BI, inflation, interest rates have nothing to do with stock prices. Results of the re-search will provide potential investors or investors or with a more careful approach to considering U.S. dollar exchange rate aspects of rupiah as an investment in terms of stock prices in connection with the conclusions. The study's results will be used by banking firms in their business choices, in particular macroeconomics decisions in terms of share prices. Business decisions focus on how far bank returns are provided and the way in which banks maintain capital levels and corporate liquidity to allow investors to become interested in the business. More companies not just in the banking industry should be used for future research. Finding a macroeconomic relationship on stock prices should also be done with further research over a longer period. More research should also be used not only for seven years with the annual audited report data for a longer period. More research is also investigating the significance in each stage of the company cycle of capital, macroeconomic and banking liquidity metrics, as is the case for Black research carried out (1998). Investment decision making by Engineering Managers needs to take into account microeconomic and macroeconomic factors in a country. The role of Engineering Managers in making decisions is crucial and very important. Technical Managers need to consider macro-economic effects such as the US dollar exchange rate against the rupiah, the interest rate set by Bank Indonesia, inflation, especially during the preparation of the Budget Plan (RAB). The research also shows that Technical Managers are very necessary to pay attention to the exchange rate of the US dollar against the rupiah in each of its investment decisions especially during the preparation of the Budget Plan (RAB) before contact is made.

\section{Acknowledgement}

This research was funded by the Indonesian Aviation Polytechnic Curug and Jayapura Aviation Polytechnic.

\section{References}

Adamović, S., Miškovic, V., Maček, N., Milosavljević, M., Šarac, M., Saračević, M., \& Gnjatović, M. (2020). An efficient novel approach for iris recognition based on stylometric features and machine learning techniques. Future Generation 
Computer Systems, 107, 144-157. https://doi.org/10.1016/j.future.2020.01.056

Ahmed, Y. A., \& Kar, B. (2019). Gender differences of entrepreneurial challenges in Ethiopia. Academy of Entrepreneurship Journal, 25(2), 1-6. https://www.scopus.com/inward/record.uri?eid=2-s2.0$85072153013 \&$ partnerID $=40 \& \mathrm{md} 5=773 \mathrm{ec} 273 \mathrm{f} 08 \mathrm{fe} 7870 \mathrm{a} 68867265 \mathrm{a} 6 \mathrm{de} 06$

Aleem, I. (1990). Imperfect information, screening, and the costs of informal lending: A study of a rural credit market in Pakistan. World Bank Economic Review, 4(3), 329-349. https://doi.org/10.1093/wber/4.3.329

Alfonsi, A., Cherchali, A., \& Infante Acevedo, J. A. (2020). A synthetic model for asset-liability management in life insurance, and analysis of the SCR with the standard formula. European Actuarial Journal, 10(2), 457-498. https://doi.org/10.1007/s13385-020-00240-3

Andari, G., Nurcahyani, E., Lesik, M. M. N. N., Panga, N. J., \& Jaya, A. M. (2019). Invitro selection resistant plantain of king bulu (Musa Paradisiaca L. Var Sapientum) on droughtas an animal. IOP Conference Series: Earth and Environmental Science, 343(1). https://doi.org/10.1088/1755-1315/343/1/012176

Anggitawati, D., \& Ekaputra, I. A. (2020). Foreign Portfolio Investment Flows and Exchange Rate: Evidence in Indonesia. Emerging Markets Finance and Trade, 56(2), 260-274. https://doi.org/10.1080/1540496X.2018.1496419

Anglada, S. E. (2016). From social innovation to the solidarity-based economy: Key practices for the development of public policies [De la innovación social a la economía solidaria. Claves prácticas para el desarrollo de políticas públicas].

CIRIEC-Espana Revista de Economia Publica, Social y Cooperativa, 88(1), 201-230.

https://www.scopus.com/inward/record.uri?eid=2-s2.0-

85011585959\&partnerID $=40 \& m d 5=6574 b 61 \mathrm{dc} 6458 \mathrm{c} 5 \mathrm{~b} 55 \mathrm{cb} 9615 \mathrm{~d} 9 \mathrm{dde} 93 \mathrm{a}$

Aslanbeigui, N., \& Oakes, G. (2015). The British tariff reform controversy and the genesis of pigou's Wealth and Welfare, 1903-12. History of Political Economy, 47, 23-48. https://doi.org/10.1215/00182702-3130427

Asmah, E. E., Kwaw Andoh, F., \& Titriku, E. (2020). Trade misinvoicing effects on tax revenue in sub-Saharan Africa: The role of tax holidays and regulatory quality. Annals of Public and Cooperative Economics, 91(4), 649-672. https://doi.org/10.1111/apce.12289

Aulin-Ahmavaara, P. (1989). A complete dynamic input-output model including the production of human capital and labour. Economic Systems Research, 1(1), 121-130. https://doi.org/10.1080/09535318900000010

Azolibe, C. B., Nwadibe, C. E., \& Okeke, C. M.-G. (2020). Socio-economic determinants of public expenditure in Africa: assessing the influence of population age structure. International Journal of Social Economics, 47(11), 1403-1418. https://doi.org/10.1108/IJSE-04-2020-0202

Bahadori, A., \& Kashiwao, T. (2019). Modeling and analysis of hydrogen production in steam methane reforming (SMR) process. Petroleum Science and Technology, 37(12), 1425-1435. https://doi.org/10.1080/10916466.2019.1587466

Bański, J., \& Wesołowska, M. (2020). Disappearing Villages in Poland-Selected Socioeconomic Processes and Spatial Phenomena. European Countryside, 12(2), 221-241. https://doi.org/10.2478/euco-2020-0013

Barasa, E., Rogo, K., Mwaura, N., \& Chuma, J. (2018). Kenya national hospital insurance fund reforms: Implications and lessons for universal health coverage. Health Systems and Reform, 4(4), 346-361. https://doi.org/10.1080/23288604.2018.1513267

Barbosa-Filho, N. H. (2020). From Dilma to Bolsonaro: Brazilian economic policy in 2011-2019 [De Dilma a Bolsonaro: La política económica de Brasil de 2011 a 2019]. Trimestre Economico, 87(347), 597-634. https://doi.org/10.20430/ETE.V87I347.1080

Bataev, A. V, Gorovoy, A. A., \& Mottaeva, A. (2018). Digital transformation of the financial sector in Russia and the world. Proceedings of the 32nd International Business Information Management Association Conference, IBIMA 2018 - Vision 2020: Sustainable Economic Development and Application of Innovation Management from Regional Expansion to Global Growth, 102-114. https://www.scopus.com/inward/record.uri?eid=2-s2.0$85063064351 \&$ partnerID $=40 \& \mathrm{md} 5=70 \mathrm{c} 879955 \mathrm{e} 3 \mathrm{a} 48 \mathrm{fd} 1$ bebcdca7d4558e 4

BC, B., \& Esfahani, S. (2020). The role of debt contracts in analyst earnings forecasts. Journal of Economics and Business, 111. https://doi.org/10.1016/j.jeconbus.2020.105929

Bersch, J., Diekhof, J., Krieger, B., Licht, G., \& Murmann, S. (2019). Productivity slowdown, innovation and industry dynamics. In From Industrial Organization to Entrepreneurship: A Tribute to David B. Audretsch. https://doi.org/10.1007/978-3-03025237-3_21

Bezemer, D., Samarina, A., \& Zhang, L. (2020). Does mortgage lending impact business credit? Evidence from a new disaggregated bank credit data set. Journal of Banking and Finance, 113. https://doi.org/10.1016/j.jbankfin.2020.105760

Blanchett, D. (2014). Donation risk and optimal endowment portfolio allocations. Journal of Portfolio Management, 41(1), 109-120. https://doi.org/10.3905/jpm.2014.41.1.109

Bordo, M. D., \& Jeanne, O. (2004). Boom-busts in asset prices, economic instability, and monetary policy. In Deflation: Current and Historical Perspectives. https://doi.org/10.1017/CBO9780511607004.006

Bouteska, A., \& Regaieg, B. (2020). Loss aversion, overconfidence of investors and their impact on market performance evidence from the US stock markets. Journal of Economics, Finance and Administrative Science, 25(50), 451-478. https://doi.org/10.1108/JEFAS-07-2017-0081

Brown, L. R., McGrath, P. L., \& Stokes, B. (1976). Twenty two dimensions of the population problem. Population Reports - 
Series $\quad J, \quad$ ser.J(11), $\quad$ 177-202. https:/www.scopus.com/inward/record.uri?eid=2-s2.00017088231\&partnerID $=40 \& m d 5=3528249156 \mathrm{c} 9$ eec67332d3cb4346db4b

Brown, S., Lo, K., \& Lys, T. (1999). Use of R 2 in Accounting Research : Measuring Changes in Value Relevance over the Last Four Decades. JEL, 847.

Bulut, H., \& Collins, K. J. (2014). Designing farm supplemental revenue coverage options on top of crop insurance coverage. Agricultural Finance Review, 74(3), 397-426. https://doi.org/10.1108/AFR-08-2013-0032

Bykanova, O. A., Akhmadeev, R. G., Kosov, M. E., Ponkratov, V. V, Osipov, V. S., \& Ragulina, Y. V. (2017). Assessment of the economic potential of sovereign wealth funds. Journal of Applied Economic Sciences, 12(1), 70-84. https://www.scopus.com/inward/record.uri?eid=2-s2.085018529810\&partnerID=40\&md5=9e2e5f5fe86f8c9e7538714cdc81ed4b

Čabinová, V., Onuferová, E., Jurová, N., \& Fedorčíková, R. (2020a). Efficiency evaluation of the medical SPA sector in Slovakia: An application of DEA method. Quality - Access to Success, 21(178), 7-14. https://www.scopus.com/inward/record.uri?eid=2-s2.0$85090876360 \&$ partnerID $=40 \& \mathrm{md} 5=3 \mathrm{a} 19430 \mathrm{c} 75 \mathrm{fla1b}$ cf6blaf61 fbf7e 86

Čabinová, V., Onuferová, E., Jurová, N., \& Fedorčíková, R. (2020b). Efficiency evaluation of the medical SPA sector in Slovakia: An application of DEA method. Journal of General Management, 21(178), 7-14. https://www.scopus.com/inward/record.uri?eid=2-s2.085095605591\&partnerID=40\&md5=7aedc083d9f921d3a3ed4c80462c431f

Cagliarini, A., Robinson, T., \& Tran, A. (2011). Reconciling microeconomic and macroeconomic estimates of price stickiness. Journal of Macroeconomics, 33(1), 102-120. https://doi.org/10.1016/j.jmacro.2010.10.003

Cai, W., \& Ye, P. (2020). How does environmental regulation influence enterprises' total factor productivity? A quasi-natural experiment based on China's new environmental protection law. Journal of Cleaner Production, 276. https://doi.org/10.1016/j.jclepro.2020.124105

Cai, X., Zhu, B., Zhang, H., Li, L., \& Xie, M. (2020). Can direct environmental regulation promote green technology innovation in heavily polluting industries? Evidence from Chinese listed companies. Science of the Total Environment, 746. https://doi.org/10.1016/j.scitotenv.2020.140810

Cancela, B. L., Neves, M. E. D., Rodrigues, L. L., \& Gomes Dias, A. C. (2020). The influence of corporate governance on corporate sustainability: new evidence using panel data in the Iberian macroeconomic environment. International Journal of Accounting and Information Management, 28(4), 785-806. https://doi.org/10.1108/IJAIM-05-2020-0068

Cardi, C., \& Mazzoli, C. (2019). The role of intangibles disclosure in Italian IPOs : An explorative study on primary and secondary market investors' reactions. European Business Review, 31(5), 688-720. https://doi.org/10.1108/EBR-08-20180146

Carvalho, A. R., Pennino, M. G., Bellido, J. M., \& Olavo, G. (2020). Small-scale shrimp fisheries bycatch: A multi-criteria approach for data-scarse situations. Marine Policy, 116. https://doi.org/10.1016/j.marpol.2019.103613

Castillo-Carmelino, J., Castro-Nagatomy, E., Perez-Paredes, M., Raymundo-Ibañez, C., \& Alvarez, J. M. (2020). Digitization Model for Reducing Costs and Operating Times in Peruvian Banks. ICITM 2020 - 2020 9th International Conference on Industrial Technology and Management, 166-170. https://doi.org/10.1109/ICITM48982.2020.9080358

Chakravarty, S., \& Ray, R. (2020). On short-term institutional trading skill, behavioral biases, and liquidity need. Journal of Corporate Finance, 65. https://doi.org/10.1016/j.jcorpfin.2020.101749

Chiang, T. C. (2020). US policy uncertainty and stock returns: evidence in the US and its spillovers to the European Union, China and Japan. Journal of Risk Finance, 21(5), 621-657. https://doi.org/10.1108/JRF-10-2019-0190

Chitradevi, K. (2019). Determinants of FIIs net investment in India. International Journal of Recent Technology and Engineering, 8(2 Special Issue 10), 609-611. https://doi.org/10.35940/ijrte.B1140.0982S1019

Cole, E. L., \& Rosengaus, R. B. (2019). Pathogenic Dynamics During Colony Ontogeny Reinforce Potential Drivers of Termite Eusociality: Mate Assistance and Biparental Care. Frontiers in Ecology and Evolution, 7. https://doi.org/10.3389/fevo.2019.00473

Craja, P., Kim, A., \& Lessmann, S. (2020). Deep learning for detecting financial statement fraud. Decision Support Systems, 139. https://doi.org/10.1016/j.dss.2020.113421

Darman, \& Hutomo, K. (2020). Inflation effect, interest rate of bank Indonesia certificates (SBI) and economic growth on rupiah exchange rate in Indonesia. Pertanika Journal of Social Sciences and Humanities, $28,261-275$. https://www.scopus.com/inward/record.uri?eid=2-s2.085090821949\&partnerID=40\&md5=bebd0f5c5efb8e8264d8a935523eb6a4

Darwanto, \& Chariri, A. (2019). Corporate governance and financial performance in Islamic banks: The role of the sharia supervisory board in multiple-layer management. Banks and Bank Systems, 14(4), 183-191. https://doi.org/10.21511/bbs.14(4).2019.17

Delgado, C. L., Narrod, C. A., Tiongco, M. M., de Camargo Barros, G. S., Catelo, M. A., Costales, A., Mehta, R., Naranong, V., Poapongsakorn, N., Sharma, V. P., \& de Zen, S. (2008). Determinants and implications of the growing scale of livestock farms in four fast-growing developing countries. Research Report of the International Food Policy Research Institute, 157, 
$\mathrm{X}-131$.

47949129008\&partnerID=40\&md5=337324dfe2a07f4ef1 c5270ab8c2beca

https://www.scopus.com/inward/record.uri?eid=2-s2.0-

Deng, G., Zhang, H., Guo, X., \& Ying, H. (2018). Assessment of Drought in Democratic People's Republic of Korea in 2017 Using TRMM Data. 5th International Workshop on Earth Observation and Remote Sensing Applications, EORSA 2018 Proceedings. https://doi.org/10.1109/EORSA.2018.8598557

Derevyankina, E. S., \& Yankovskaya, D. G. (2020). The impact of Covid-19 on supply chain management and global economy development. International Journal of Supply Chain Management, 9(4), 765-774. https://www.scopus.com/inward/record.uri?eid=2-s2.085089973672\&partnerID=40\&md5=a901af3d49c9bd28d380f0091f978f56

Dernbach, J. C. (2004). Toward a climate change strategy for Pennsylvania. Penn State Environmental Law Review, 12(1), 181205. https://www.scopus.com/inward/record.uri?eid=2-s2.02942648324\&partnerID=40\&md5=84805f3a6d81af30cbac6459dc0d5e1e

Do, V., Nguyen, T. H., Truong, C., \& Vu, T. (2020). Is drought risk priced in private debt contracts? International Review of Finance. https://doi.org/10.1111/irfi.12294

Drometer, M., Franko, M., Pérez, M. H., Rhode, C., Schworm, S., \& Stitteneder, T. (2018). Wealth and inheritance taxation: An overview and country comparison. CESifo DICE Report, 16(2), 45-54. https://www.scopus.com/inward/record.uri?eid=2-s2.085051666602\&partnerID $=40 \& \mathrm{md} 5=\mathrm{c} 372 \mathrm{~b} 1301592 \mathrm{c} 884383350 \mathrm{fe} 4 \mathrm{~b} 9 \mathrm{~d} 6 \mathrm{bea}$

Eberhartinger, E., Genest, N., \& Lee, S. (2020). Financial statement users' judgment and disaggregated tax disclosure. Journal of International Accounting, Auditing and Taxation, 41. https://doi.org/10.1016/j.intaccaudtax.2020.100351

Erratum regarding missing Declaration of Competing Interest statements in previously published articles (Journal of Accounting Education (2020) 51, (S0748575120300245), (10.1016/j.jaccedu.2020.100670)). (2020). Journal of Accounting Education, 53. https://doi.org/10.1016/j.jaccedu.2020.100696

Ertimur, Y., Francis, J., Gonzales, A., \& Schipper, K. (2020). Financial reporting for pollution reduction programs. Management Science, 66(12), 6015-6041. https://doi.org/10.1287/mnsc.2019.3416

Escobar, A. L., López, R. R., Solano-Sánchez, M. Á., \& García, M. B. G.-M. (2020). The role of complementary monetary system as an instrument to innovate the local financial system. Journal of Open Innovation: Technology, Market, and Complexity, 6(4), 1-19. https://doi.org/10.3390/joitmc6040141

Fahy Bryceson, D., \& Bosse Jønsson, J. (2013). Mineralizing Africa and artisanal Mining's democratizing influence. In Mining and Social Transformation in Africa: Mineralizing and Democratizing Trends in Artisanal Production. https://doi.org/10.4324/978020362747-7

Farjadi, G., Amini, A., \& Alaedini, P. (2018). Employment of highly educated labor force in Iran: Challenges and prospects through the sixth development plan and beyond. In Industrial, Trade, and Employment Policies in Iran: Towards a New Agenda. https://doi.org/10.1007/978-3-319-94012-0_9

Feltham, G. A., \& Ohlson, J. A. (1995). Valuation and clean surplus accounting for operating and financial activities. Contemporary Accounting Research, 11(2), 689-731.

Fidiastutik, D. I., \& Roziq, A. (2019). Financing, cash flow, risk, profitability and islamic social responsibility of islamic banks in Indonesia. International Journal of Scientific and Technology Research, 8(8), 69-74. https://www.scopus.com/inward/record.uri?eid=2-s2.085071366506\&partnerID=40\&md5=041336f04fd53712d3975e177b36bd6e

Flores-Muñoz, F., Báez-García, A. J., \& Gutiérrez-Barroso, J. (2019). Fractional differencing in stock market price and online presence of global tourist corporations. Journal of Economics, Finance and Administrative Science, 24(48), 194-204. https://doi.org/10.1108/JEFAS-01-2018-0013

Fooladi, I. J., Jacoby, G., \& Jin, L. (2020). Real duration and inflation duration: A cross country perspective on a multidimensional hedging strategy. Journal of International Financial Markets, Institutions and Money. https://doi.org/10.1016/j.intfin.2020.101265

Fullerton, T. M., \& Muñiz, E. P. (2020). Credit union loan rate determinants in the United States. Applied Economics, 52(49), 5413-5425. https://doi.org/10.1080/00036846.2020.1764481

Gajek, L., \& Rudź, M. (2020). Finite-Horizon Ruin Probabilities in a Risk-Switching Sparre Andersen Model. Methodology and Computing in Applied Probability, 22(4), 1493-1506. https://doi.org/10.1007/s11009-018-9627-2

Gamble, A. (2018). The 2008 crisis and the resilience of the neo-liberal order. In The Pedagogy of Economic, Political and Social Crises: Dynamics, Construals and Lessons. https://doi.org/10.4324/9781315161587

Gelfer, S. (2020). Re-evaluating Okun's Law: Why all recessions and recoveries are "different." Economics Letters, 196. https://doi.org/10.1016/j.econlet.2020.109497

Glawe, L., \& Wagner, H. (2020). China in the middle-income trap? China Economic Review, 60. https://doi.org/10.1016/j.chieco.2019.01.003

Gut, S., Chervet, A., Stettler, M., Weisskopf, P., Sturny, W. G., Lamandé, M., Schjønning, P., \& Keller, T. (2015). Seasonal dynamics in wheel load-carrying capacity of a loam soil in the Swiss Plateau. Soil Use and Management, 31(1), 132-141. https://doi.org/10.1111/sum.12148 
Hasan, M. M., Cheung, A. W. K., \& Taylor, G. (2020). Financial statement comparability and bank risk-taking. Journal of Contemporary Accounting and Economics, 16(3). https://doi.org/10.1016/j.jcae.2020.100206

Helbekkmo, H., Levy, C., \& White, O. (2019). Creating the bank enterprise risk management function of the future. Journal of Risk Management in Financial Institutions, 12(4), 297-310. https:/www.scopus.com/inward/record.uri?eid=2-s2.085074496106\&partnerID=40\&md5=53e963446e0b61236129d0ebbd5f9381

Hindess, B. (2017). Liberty and equality. In Reactions to the Right. https://doi.org/10.4324/9781315276328

$\mathrm{Hu}$, Y., \& Song, X. (2020). Research on the impact of performance compensation commitments on the interests of small and medium-sized shareholders. Conference Proceedings of the 8th International Symposium on Project Management, ISPM 2020, 123-128. https://www.scopus.com/inward/record.uri?eid=2-s2.085091899634\&partnerID $=40 \& \mathrm{md} 5=156 \mathrm{c} 763 \mathrm{accc} 7 \mathrm{~b} 84 \mathrm{aed} 313729 \mathrm{c} 1 \mathrm{e} 40484$

Huang, F., Zhu, J., Zhang, X., Liu, T., \& Zhu, Y. (2020). Unsupervised feature selection and fragmentation optimization of agriculture management zones at a regional scale [区域尺度农业管理分区的无监督特征选择与破碎度优化算法]. Nongye Gongcheng Xuebao/Transactions of the Chinese Society of Agricultural Engineering, 36(5), 192-200. https://doi.org/10.11975/j.issn.1002-6819.2020.05.022

Hubmann, G., Jobst, C., \& Maier, M. (2020). A new long-run consumer price index for Austria, 1800-2018 [Ein neuer langer verbraucherpreisindex für österreich, 1800-2018]. Vierteljahresschrift Fur Sozial Und Wirtschaftsgeschichte, 107(1), 4785. https://doi.org/10.25162/VSWG-2020-0002DUMMY

Humpe, A., \& McMillan, D. (2020). The Covid-19 Stock Market Puzzle and Money Supply in the US. Economics Bulletin, 40(4), 3104-3110. https://www.scopus.com/inward/record.uri?eid=2-s2.085098152089\&partnerID=40\&md5=8901 fe19521a7179862fcf98b66c199a

Iqbal Anjum, M. (1996). Eternal Challenge of Islamic Economics to Capitalism and Communism. Humanomics, 12(1), 53-90. https://doi.org/10.1108/eb018771

Jonáš, J. (2001). Monetary Policy in the Czech Republic and EMU Accession [Měnová politika ČR před vstupem do EMU]. Finance a Uver - Czech Journal of Economics and Finance, 2001(9), 472-486.

https://www.scopus.com/inward/record.uri?eid=2-s2.00347628160\&partnerID=40\&md5=25b15e2fe5e0b7b97042dc8951b30007

Juanamasta, I. G., Wati, N. M. N., Hendrawati, E., Wahyuni, W., Pramudianti, M., Wisnujati, N. S., Setiawati, A. P., Susetyorini, S., Elan, U., Rusdiyanto, R., Muharlisiani, L. T., \& Umanailo, M. C. B. (2019). The role of customer service through customer relationship management $(\mathrm{Crm})$ to increase customer loyalty and good image. International Journal of Scientific and Technology Research, 8(10), 2004-2007.

Jumpah, E. T., Ampadu-Ameyaw, R., \& Owusu-Arthur, J. (2020). Youth employment in Ghana: economic and social development policies perspective. World Journal of Entrepreneurship, Management and Sustainable Development, 16(4), 413-427. https://doi.org/10.1108/WJEMSD-07-2019-0060

Karlsson, S., \& Österholm, P. (2020). A hybrid time-varying parameter Bayesian VAR analysis of Okun's law in the United States. Economics Letters, 197. https://doi.org/10.1016/j.econlet.2020.109622

Kartika, T., Firdaus, A., \& Najib, M. (2019). Contrasting the drivers of customer loyalty; financing and depositor customer, single and dual customer, in Indonesian Islamic bank. Journal of Islamic Marketing, 11(4), 933-959. https://doi.org/10.1108/JIMA-04-2017-0040

Kim, J., Song, Y., Kim, D. W., Fiaz, M., \& Kwon, C. H. (2018). Evaluating different interrow distance between corn and soybean for optimum growth, production and nutritive value of intercropped forages. Journal of Animal Science and Technology, 60(1). https://doi.org/10.1186/s40781-017-0158-0

Kind, J., Botzen, W. J. W., \& Aerts, J. C. J. H. (2020). Social vulnerability in cost-benefit analysis for flood risk management. Environment and Development Economics, 25(2), 115-134. https://doi.org/10.1017/S1355770X19000275

Krishnan, R., Agarwal, R., Bajada, C., \& Arshinder, K. (2020). Redesigning a food supply chain for environmental sustainability - An analysis of resource use and recovery. Journal of Cleaner Production, 242. https://doi.org/10.1016/j.jclepro.2019.118374

Kuhl, L., Van Maanen, K., \& Scyphers, S. (2020). An analysis of UNFCCC-financed coastal adaptation projects: Assessing patterns of project design and contributions to adaptive capacity. World Development, 127. https://doi.org/10.1016/j.worlddev.2019.104748

Kupiec, P. H. (2020). Policy uncertainty and bank stress testing. Journal of Financial Stability, 51. https://doi.org/10.1016/j.jfs.2020.100761

Leith, C., \& Wren-Lewis, S. (2009). Taylor rules in the open economy. European Economic Review, 53(8), 971-995. https://doi.org/10.1016/j.euroecorev.2009.04.009

Li, P., Han, Y., Lin, S., \& Qiao, T. (2020). Chinese write-down bonds: issuance and bank capital structure. Quantitative Finance, 20(12), 2055-2065. https://doi.org/10.1080/14697688.2020.1814034

Li, T., Liu, J., Wang, L., Zhu, H., \& Yu, L. (2017). Spatial differences in international investment in hotels and its driving factors in China. Dili Xuebao/Acta Geographica Sinica, 72(10), 1904-1919. https://doi.org/10.11821/dlxb201710013

Lien, V. T. P., Van Hoi, T., \& Anh, P. T. K. (2020). STRENGTHENING INTERNAL AUDIT AT PUBLIC COMPANIES TO 
IMPROVE THE QUALITY OF FINANCIAL STATEMENTS: A CASE STUDY OF HANOI STOCK EXCHANGE, VIETNAM. Academy of Strategic Management Journal, 19(6), 1-10. https://www.scopus.com/inward/record.uri?eid=2s2.0-85098229437\&partnerID $=40 \& \mathrm{md} 5=5379 \mathrm{~d} 1 \mathrm{fle} 0849 \mathrm{f} 31 \mathrm{ae} 54200 \mathrm{ac} 6 \mathrm{a} 37 \mathrm{~d} 3 \mathrm{c}$

Luque, J. (2020). Cross-Border Residential Lending: Theory and Evidence from the European Sovereign Debt Crisis. Real Estate Economics, 48(4), 1136-1167. https://doi.org/10.1111/1540-6229.12214

Lynn, T. J., Garza, M. D. L., \& Haces-Garcia, F. (2020). Reclaimed Water Holding Pond Treatment Using Wood Chip Biofilters. World Environmental and Water Resources Congress 2020: Water Resources Planning and Management and Irrigation and Drainage - Selected Papers from the Proceedings of the World Environmental and Water Resources Congress 2020, 102-108. https://doi.org/10.1061/9780784482957.011

Mahboob, Q., Stoiber, T., Gottstein, S., \& Tsakarestos, A. (2012). An approach to calculate overall efficiency of rolling stock for an urban rail transit system. Journal of Public Transportation, 15(1), 19-32. https://doi.org/10.5038/2375-0901.15.1.2

Malanima, P. (2018). Italy in the Renaissance: a leading economy in the European context, 1350-1550. Economic History Review, 71(1), 3-30. https://doi.org/10.1111/ehr.12650

Malkiel, B. G., \& Fama, E. F. (1970). Efficient capital markets: A review of theory and empirical work. The Journal of Finance, 25(2), 383-417.

Mallett, W. J., Maguire, S., \& Kosar, K. R. (2012). National infrastructure bank: Overview and current legislation. In National Infrastructure Bank: Concept and Proposals. https://www.scopus.com/inward/record.uri?eid=2-s2.084934287578\&partnerID $=40 \& m d 5=b b 80523185 a 2 f 2 d f e d 252 \mathrm{fd} 4 \mathrm{c} 8005 \mathrm{c} 9 \mathrm{a}$

Manzoor, D., \& Haqiqi, I. (2012). Impact of energy price reform on environmental emissions; A computable general equilibrium approach. Journal of Environmental Studies, 37(60), 1-12. https://www.scopus.com/inward/record.uri?eid=2-s2.084860112375\&partnerID=40\&md5=798ddc1883f819084fd54395a834ea71

Martens, W., Yapa, P. W. S., \& Safari, M. (2020). The impact of financial statement comparability on earnings management: Evidence from frontier markets. International Journal of Financial Studies, 8(4), 1-25. https://doi.org/10.3390/ijfs8040073

Martín Álvarez, J. M., Almeida, A., Galiano, A., \& Golpe, A. A. (2020). Asymmetric behavior of tobacco consumption in Spain across the business cycle: a long-term regional analysis. International Journal of Health Economics and Management, 20(4), 391-421. https://doi.org/10.1007/s10754-020-09286-y

Martin, S., Rieple, A., Chang, J., Boniface, B., \& Ahmed, A. (2015). Small farmers and sustainability: Institutional barriers to investment and innovation in the Malaysian palm oil industry in Sabah. Journal of Rural Studies, 40, 46-58. https://doi.org/10.1016/j.jrurstud.2015.06.002

Mehmood, A., Maung, Z., Consunji, R. J., El-Menyar, A., Peralta, R., Al-Thani, H., \& Hyder, A. A. (2018). Work related injuries in Qatar: A framework for prevention and control. Journal of Occupational Medicine and Toxicology, 13(1). https://doi.org/10.1186/s12995-018-0211-z

Millar, J. (2009). Tax credits. In Understanding Social Security: Issues for Policy and Practice: Second Edition. https://www.scopus.com/inward/record.uri?eid=2-s2.0-

84979035043\&partnerID=40\&md5=d67206df6b054b584af5b9bba676d027

Minot, N., Epprecht, M., Anh, T. T. T., \& Trung, L. Q. (2006). Income diversification and poverty in the Northern Uplands of Vietnam. Research Report of the International Food Policy Research Institute, 145, 1-137. https://doi.org/10.2499/0896291480

Mousavian, S. N., \& Eskandari, H. (2018). Allelopathic effect of two medicinal plants on seed germination, seedling growth and grain production of purslane (Portulaca oleraceae L.) weed. Acta Agriculturae Slovenica, 111(2), 293-301. https://doi.org/10.14720/aas.2018.111.2.05

Mukhibad, H., \& Setiawan, D. (2020). Could risk, corporate governance, and corporate ethics enhance social performance? Evidence from Islamic Banks in Indonesia. Indian Journal of Finance, 14(4), 24-38. https://doi.org/10.17010/ijf/2020/v14i4/151706

Murthy, V. N. R., \& Ketenci, N. (2020). Capital mobility in Latin American and Caribbean countries: new evidence from dynamic common correlated effects panel data modeling. Financial Innovation, 6(1). https://doi.org/10.1186/s40854-02000204-2

Navas, J., Dhanavanthan, P., \& Lazar, D. (2020). How efficient are Indian banks in managing the risk-return trade-off? An empirical analysis. Risks, 8(4), 1-13. https://doi.org/10.3390/risks8040135

Nguyen, J., \& Valadkhani, A. (2020). Dynamic responses of tourist arrivals in Australia to currency fluctuations. Journal of Hospitality and Tourism Management, 45, 71-78. https://doi.org/10.1016/j.jhtm.2020.07.003

Nguyen, P. H., Tsai, J. F., Nguyen, H. P., Nguyen, V. T., \& Dao, T. K. (2020). Assessing the Unemployment Problem Using A Grey MCDM Model under COVID-19 Impacts: A Case Analysis from Vietnam. Journal of Asian Finance, Economics and Business, 7(12), 53-62. https://doi.org/10.13106/JAFEB.2020.VOL7.NO12.053

Nguyen, T. (2011). US macroeconomic news spillover effects on Vietnamese stock market. Journal of Risk Finance, 12(5), 389-399. https://doi.org/10.1108/15265941111176127

Nguyen, T. K., \& Razali, M. N. (2020). The dynamics of listed property companies in Indonesia. Journal of Property Investment and Finance, 38(2), 91-106. https://doi.org/10.1108/JPIF-06-2019-0073

Ohlson, J. (1995). Earnings, book-values, and dividends in equity valuation. Contemporary Accounting Research, 11(2), 661- 
687. https://doi.org/10.1111/j.1911-3846.1995.tb00461.x

Osazevbaru, H. O., \& Tarurhor, E. M. (2020). Unobservable characteristics of board directors and the performance of financial services firms in Nigeria. Investment Management and Financial Innovations, 17(4), 378-388. https://doi.org/10.21511/imfi.17(4).2020.32

Ozdemir, O., Erkmen, E., \& Kim, M. (2020). Corporate social responsibility and idiosyncratic risk in the restaurant industry: does brand diversification matter? International Journal of Contemporary Hospitality Management, 32(9), $2925-2946$. https://doi.org/10.1108/IJCHM-03-2020-0167

Pennerstorfer, A., Reitzinger, S., \& Schneider, U. (2020). The Scarring Effect of the 2008 Economic Crisis: Growth and Growth Decline in Austria's Nonprofit Social Services Sector. Voluntas, 31(6), 1173-1187. https://doi.org/10.1007/s11266-02000234-5

Ploch, L. (2011). Zimbabwe: The power sharing agreement and implications for U.S. Policy. In Politics and Economics of Africa (Vol. 7). https://www.scopus.com/inward/record.uri?eid=2-s2.085048071200\&partnerID=40\&md5=0439d9aa0f41e8b5fc71e1548c4aadb3

Pollard, C. M., Booth, S., Louth, J., Mackenzie, C., \& Goodwin-Smith, I. (2020). "I'd be sleeping in the park, I reckon": Lived Experience of Using Financial Counselling Services in South Australia*. Economic Papers, 39(4), $353-366$. https://doi.org/10.1111/1759-3441.12298

Prabowo, B., Rochmatulaili, E., Rusdiyanto, \& Sulistyowati, E. (2020). Corporate governance and its impact in company's stock price: case study [Gobernabilidad corporativa y su impacto en el precio de las acciones de las empresas: Estudio de caso]. Utopia y Praxis Latinoamericana, 25(Extra10), 187-196. https://doi.org/10.5281/zenodo.4155459

Prices: No inflation fear. (2000). Petroleum Economist, 67(1), 38. https://www.scopus.com/inward/record.uri?eid=2-s2.00033965787\&partnerID=40\&md5=73365dde97dd24ff464616c6dd0100ac

Rabbani, N. (2020). Determinants of Capital Structure: Insights from Japanese Private Firms. Asia-Pacific Financial Markets, 27(4), 587-603. https://doi.org/10.1007/s10690-020-09307-3

Rahim, M., Millia, H., Adam, P., \& Saidi, L. O. (2020). Causality relation among export, import and exchange rate in indonesia. International Journal of Scientific and Technology Research, 9(3), 3096-3102. https://www.scopus.com/inward/record.uri?eid=2-s2.085082594086\&partnerID=40\&md5=e014f6ee 0481c71 ee354e8b14ca70008

Ramli, R., Febrian, E., Masyita, D., \& Anwar, M. (2020). Risk determinant of musharakah financing: A study in Indonesia. ACRN Journal of Finance and Risk Perspectives, 9(1), 45-56. https://doi.org/10.35944/jofrp.2020.9.1.004

Rehfeldt, M., Fleiter, T., Herbst, A., \& Eidelloth, S. (2020). Fuel switching as an option for medium-term emission reduction A model-based analysis of reactions to price signals and regulatory action in German industry. Energy Policy, 147. https://doi.org/10.1016/j.enpol.2020.111889

Ren, A., Sun, M., Xue, L., Deng, Y., Wang, P., Lei, M., Xue, J., Lin, W., Yang, Z., \& Gao, Z. (2019). Spatio-temporal dynamics in soil water storage reveals effects of nitrogen inputs on soil water consumption at different growth stages of winter wheat. Agricultural Water Management, 216, 379-389. https://doi.org/10.1016/j.agwat.2019.01.023

Ricci, F., Scafarto, V., Ferri, S., \& Tron, A. (2020). Value relevance of digitalization: The moderating role of corporate sustainability. An empirical study of Italian listed companies. Journal of Cleaner Production, 276. https://doi.org/10.1016/j.jclepro.2020.123282

Robinson, B., \& Wade, K. (1985). The London Business School with Gower Publishing. Economic Outlook, 9(10), 1-4. https://doi.org/10.1111/j.1468-0319.1985.tb00226.x

Rusdiyanto, Agustia, D., Soetedjo, S., \& Septiarini, D. F. (2020). The effect of cash turnover and receivable turnover on profitability $\mid$ El efecto de la rotación de efectivo y la rotación de cuentas por cobrar en la rentabilidad. Opcion, 36(Special Ed), 1417-1432.

Rusdiyanto, Hidayat, W., Tjaraka, H., Septiarini, D. F., Fayanni, Y., Utari, W., Waras, Indrawati, M., Susanto, H., Tjahjo, J. D. W., Zainal, M., \& Imanawati, Z. (2020). The effect of earning per share, debt to equity ratio and return on assets on stock prices: Case study Indonesian. Academy of Entrepreneurship Journal, 26(2), 1-10.

Saenong, Z., Muthalib, A. A., Adam, P., Rumbia, W. A., Millia, H., \& Saidi, L. O. (2020). Symmetric and asymmetric effect of crude oil prices and exchange rate on bond yields in Indonesia. International Journal of Energy Economics and Policy, 10(2), 95-100. https://doi.org/10.32479/ijeep.8878

Saidi, L. O., Aedy, H., Saranani, F., Rosnawintang, Adam, P., \& Sani, L. O. A. (2020). Crude oil price and exchange rate: An analysis of the asymmetric effect and volatility using the non linear autoregressive distributed lag and general autoregressive conditional heterochedasticity in mean models. International Journal of Energy Economics and Policy, 10(1), 104-108. https://doi.org/10.32479/ijeep.8362

Samy-Kamal, M. (2020). Outlook on the fisheries policy reform in Egypt and the draft of the new fisheries law. Marine Policy, 120. https://doi.org/10.1016/j.marpol.2020.104136

Sandberg, J. (2015). What's wrong with exorbitant interest rates on microloans? In Microfinance, Rights and Global Justice. https://doi.org/10.1017/CBO9781316275634.008

Sapienza, P. (2004). The effects of government ownership on bank lending. Journal of Financial Economics, 72(2), 357-384. 
https://doi.org/10.1016/j.jfineco.2002.10.002

Sauzède, R., Martinez, E., Maes, C., de Fommervault, O., Poteau, A., Mignot, A., Claustre, H., Uitz, J., Oziel, L., Maamaatuaiahutapu, K., Rodier, M., Schmechtig, C., \& Laurent, V. (2020). Enhancement of phytoplankton biomass leeward of Tahiti as observed by Biogeochemical-Argo floats. Journal of Marine Systems, 204. https://doi.org/10.1016/j.jmarsys.2019.103284

Schlüter, S., Zawallich, J., Vogel, H.-J., \& Dörsch, P. (2019). Physical constraints for respiration in microbial hotspots in soil and their importance for denitrification. Biogeosciences, 16(18), 3665-3675. https://doi.org/10.5194/bg-16-3665-2019

Schuenemann, J.-H., Ribberink, N., \& Katenka, N. (2020). Japanese and Chinese Stock Market Behaviour in Comparison - an analysis of dynamic networks. Asia Pacific Management Review, 25(2), 99-110. https://doi.org/10.1016/j.apmrv.2019.10.002

Shanaev, S., Shimkus, N., Ghimire, B., \& Sharma, S. (2020). Children's toy or grown-ups' gamble? LEGO sets as an alternative investment. Journal of Risk Finance, 21(5), 577-620. https://doi.org/10.1108/JRF-02-2020-0021

Shen, S., Li, F., \& Tanui, J. K. (2012). Quality of Life and Old Age Social Welfare System for the Rural Elderly in China. Ageing International, 37(3), 285-299. https://doi.org/10.1007/s12126-011-9130-3

Sherer Jr., R. D., Bronson, J. D., Teter, C. J., \& Wykoff, R. F. (2004). Microeconomic loans and health education to families in impoverished communities: Implications for the HIV pandemic. Journal of the International Association of Physicians in AIDS Care, 3(4), 110-114. https://doi.org/10.1177/154510970400300402

Shishany, A. A., Al-Omush, A., \& Guermat, C. (2020). The impact of economic value added (EVA) adoption on stock performance. Accounting, 6(5), 687-704. https://doi.org/10.5267/j.ac.2020.6.015

Shorter, G., \& Seitzinger, M. V. (2012). Credit rating agencies and their regulation. In Credit Rating Agencies: Regulation and Reform Act Review. https://www.scopus.com/inward/record.uri?eid=2-s2.084936140577\&partnerID=40\&md5=a627c5c4ce73200a86bfaacb7a7b1e0a

Silver, M. (2000). Bias in the compilation of consumer price indices when different models of an item co-exist. Statistical Journal of the United Nations Economic Commission for Europe, 17(1), 13-24. https://doi.org/10.3233/sju-2000-17102

Sims, C. A. (1999). The precarious fiscal foundations of EMU. Economist, 147(4), 415-436. https://doi.org/10.1023/A:1003819626903

Škare, M. (2012). Discovering the true nature of inflation. In Inflation, Deflation and Disinflation. https://www.scopus.com/inward/record.uri?eid=2-s2.084896558320\&partnerID=40\&md5=0b96d0c0f7323aa9ecbb495cddb67574

Smaoui, H., Mimouni, K., Miniaoui, H., \& Temimi, A. (2020). Funding liquidity risk and banks' risk-taking: Evidence from Islamic and conventional banks. Pacific Basin Finance Journal, 64. https://doi.org/10.1016/j.pacfin.2020.101436

Stenning, P. C., \& Shearing, C. D. (1984). Corporate justice: Some preliminary thoughts. Australian \&amp; New Zealand Journal of Criminology, 17(2), 79-86. https://doi.org/10.1177/000486588401700203

Sutherland, D. L., \& Ralph, P. J. (2019). Microalgal bioremediation of emerging contaminants - Opportunities and challenges. Water Research, 164. https://doi.org/10.1016/j.watres.2019.114921

Syafii, M., Ulum, B., Rusdiyanto, Suparman, P., Rahayu, D. I., \& Syasindy, N. B. (2020). The effect of financial performance on the company's share price: A case study Indonesian. European Journal of Molecular and Clinical Medicine, 7(8), 1055-1071. https://www.scopus.com/inward/record.uri?eid=2-s2.085098454552\&partnerID=40\&md5=10d4ddcf32dd4bf918ba3622c11e86dd

Tharp, D. T. (2020). Consumer perceptions of financial advisory titles in the United States and implications for title regulation. International Journal of Consumer Studies, 44(6), 597-615. https://doi.org/10.1111/ijcs.12597

The budget and economic outlook: Fiscal years 2010 to 2020. (2011). In From Surplus to Deficit: The Impact of Legislation on the Federal Budget. https://www.scopus.com/inward/record.uri?eid=2-s2.084934325467\&partnerID=40\&md5=353db8d40ecae749d48cd0e17d2b4af4

Tran, D. V, Hassan, M. K., Paltrinieri, A., \& Nguyen, T. D. U. C. (2020). THE DETERMINANTS of BANK CAPITAL STRUCTURE in the WORLD. Singapore Economic Review, 65(6), 1457-1489. https://doi.org/10.1142/S0217590820500010

Turner, J. A., \& Giordano, S. (2020). AUM-Based compensation and financial advice. Journal of Retirement, 8(2), 84-99. https://doi.org/10.3905/JOR.2020.1.074

Tyler, T. R. (1982). Personalization in attributing responsibility for national problems to the president. Political Behavior, 4(4), 379-399. https://doi.org/10.1007/BF00986970

Ueda, K., \& Sharma, S. (2020). Listing advantages around the world. Journal of the Japanese and International Economies, 58. https://doi.org/10.1016/j.jjie.2020.101089

Usman, M., \& Nichol, J. E. (2020). A spatio-temporal analysis of rainfall and drought monitoring in the Tharparkar region of Pakistan. Remote Sensing, 12(3). https://doi.org/10.3390/rs12030580

Vaona, A. (2013). Money illusion and the long-run Phillips curve in staggered wage-setting models. Research in Economics, 67(1), 88-99. https://doi.org/10.1016/j.rie.2012.09.003

Vukovic, D., Ugolnikov, V., \& Maiti, M. (2020). Analyst says a lot, but should you listen? Evidence from Russia. Journal of Economic Studies, 47(4), 729-745. https://doi.org/10.1108/JES-10-2018-0352 
Walossek, D., Høeg, J. T., \& Shirley, T. C. (1996). Larval development of the rhizocephalan cirripede Briarosaccus tenellus (Maxillopoda: Thecostraca) reared in the laboratory: A scanning electron microscopy study. Hydrobiologia, 328(1), 9-47. https://doi.org/10.1007/BF00016898

Wang, X., Wang, X., Li, B., \& Bai, Z. (2019). The nonlinear characteristics of Chinese stock index futures yield volatility: Based on the high frequency data of CSI300 stock index futures. China Finance Review International, 10(2), $175-196$. https://doi.org/10.1108/CFRI-07-2018-0069

Wang, Z. J., Zhang, H., \& Zhang, X. (2020). Fire sales and impediments to liquidity provision in the corporate bond market. Journal of Financial and Quantitative Analysis, 55(8), 2613-2640. https://doi.org/10.1017/S0022109019000991

Welfens, P. J. J., \& Kauffmann, A. (2005). Structural change, natural resources sector expansion and growth in Russia. In Internationalization and Economic Policy Reforms in Transition Countries. https://doi.org/10.1007/3-540-29047-8_2

Wilson, F., Post, J., Grzywinski, R., \& Houghton, M. (2014). Social innovation and investment: The ShoreBank experience. Critical Studies on Corporate Responsibility, Governance and Sustainability, 7, 65-89. https://doi.org/10.1108/S2043905920140000007003

Yalcin, O., Ortiz, D., Tsai, A. G., Johnson, P. C., \& Cabrales, P. (2014). Microhemodynamic aberrations created by transfusion of stored blood. Transfusion, 54(4), 1015-1027. https://doi.org/10.1111/trf.12361

Yang, J., Li, W., Zhu, Q., Yang, M., Li, J., Zhang, J., Yang, B., \& Zhao, X. (2019). Identification, Formation, and Predicted Toxicity of Halogenated DBPs Derived from Tannic Acid and Its Biodegradation Products. Environmental Science and Technology, 53(22), 13019-13030. https://doi.org/10.1021/acs.est.9b03073

Yang, P. R. (2020). Using the yield curve to forecast economic growth. Journal of Forecasting, 39(7), 1057-1080. https://doi.org/10.1002/for.2676

Yılmaz, M. K., Aksoy, M., \& Çelik, T. T. (2020). Market reaction to regulatory policy changes in financial statements filings: evidence from Turkey. Eurasian Economic Review, 10(4), 567-605. https://doi.org/10.1007/s40822-020-00142-5

Yu, P. L. H., Ng, F. C., \& Ting, J. K. W. (2020). Adjusting covariance matrix for risk management. Quantitative Finance, 20(10), 1681-1699. https://doi.org/10.1080/14697688.2020.1739737

Yücel, M. (2018). Oil and the economy: evolution not revolution. Business Economics, 53(4), 225-231. https://doi.org/10.1057/s11369-018-0098-9

Yusnaini, \& Nur, I. (2020). The plankton abundance fluctuation in traditional ponds by the use of organic fertilizer from poultry manure. IOP Conference Series: Earth and Environmental Science, 465(1). https://doi.org/10.1088/1755$1315 / 465 / 1 / 012041$

Zakharchenko, O. V, Alieksieichuk, O. O., Kliuchnyk, A. V, Shyriaieva, N. Y., \& Kudlai, I. V. (2020). State support of agricultural producers as a factor in increasing the competitiveness of the agricultural sector. Entrepreneurship and Sustainability Issues, 8(1), 687-704. https://doi.org/10.9770/jesi.2020.8.1(47)

Zhan, X., Mu, Y., Nishant, R., \& Singhal, V. R. (2020). When Do Appointments of Chief Digital or Data Officers (CDOs) Affect Stock Prices\&amp;\#x003F; IEEE Transactions on Engineering Management. https://doi.org/10.1109/TEM.2020.2984619

Zhang, Y., Yao, D., \& Zhang, C. (2020). Bank loan versus financial lease: how do traditional and innovative approaches within the banking sector influence economic growth? A comparative analysis between the US and China. Applied Economics, 52(40), 4366-4383. https://doi.org/10.1080/00036846.2020.1735617

Zhenyu, S., \& Taltavull, P. (2020). International capital movement towards the Spanish real estate sector. Journal of Property Investment and Finance, 38(2), 107-127. https://doi.org/10.1108/JPIF-05-2019-0067

Zulfikar, Z., \& Sri, W. (2019). The impact of discretionary loan loss provision of sharia financing on financial performance. Banks and Bank Systems, 14(4), 34-41. https://doi.org/10.21511/bbs.14(4).2019.04

Zveryakov, M., Kovalenko, V., Sheludko, S., \& Sharah, E. (2019). FinTech sector and banking business: Competition or symbiosis? Economic Annals-XXI, 175(1-2), 53-57. https://doi.org/10.21003/ea.V175-09

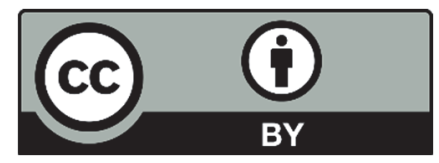

(C) 2021 by the authors; licensee Growing Science, Canada. This is an open access article distributed under the terms and conditions of the Creative Commons Attribution (CC-BY) license (http://creativecommons.org/licenses/by/4.0/). 